\title{
Local Government Innovation in Agriculture Development: A Case Study of Bantaeng Regency, Indonesia
}

\author{
Badu Ahmad \\ Department of Administrative Science, Hasanuddin University, Makassar, Indonesia \\ (email: baduahmad7@gmail.com) \\ Andi Ahmad Yani \\ Rakhmat
}

\begin{abstract}
The study of local government innovation in arts development aims to comprehensively reveal and explain the forms of innovation applied by the Bantaeng Regency Government in accelerating agricultural development in the fields of horticulture, plantations and animal husbandry. This study uses a descriptive qualitative approach with phenomenological research to describe and explain the contribution of agricultural innovation in improving farmer welfare and food security in Bantaeng Regency. To obtain valid information, informants are determined by purposive sampling.To government officials and farmer groups involved in the fields of horticulture, plantations and animal husbandry with the hope that the interviewed informants and the implementation of the FGD understand the substance of the problem. The results of the study show that there are two main reasons for local governments to innovate in the agricultural sector, including the increasing population of 187,626 people. and agricultural land is increasingly limited, covering an area of 27,074.45 hectares. There are thirteen innovations implemented in accelerating agricultural development in Bantaeng Regency. these agricultural innovations include: regency producing seed technology based movement cropping systems legowo-21, agro-area development, enterprises owned by village, agricultural products processing, development engineering insemination cattle, utilizing waste livestock for biogas in rural areas, utilizing food waste for livestock feeding, breeding Bantaeng taro, cultivating special durian without aroma and season, cattle business insurance, rice planting insurance, guaranteed availability of fertilizers and seeds.
\end{abstract}

\section{Keywords:}

local government; development; government innovation; agriculture

\section{Introduction}

The population of Bantaeng Regency in 2019 is 187,626 people and agricultural land is increasingly limited to an area of $27,074.45$ hectares and in general people work in the agricultural sector, the local government of Bantaeng Regency must make various 
breakthroughs in the development of the agricultural sector. Based on data from the National Labor Force Survey in August 2019, the working age population (15 years and over) of Bantaeng Regency in 2019 was 136,680 people and the labour force participation Rate (TPAK) reached 71.78 percent. Meanwhile, the total workforce in the open unemployment category was 3,903 people, so that the unemployment rate reached 3.98 percent. The population of working age who are included in the open unemployment has the most recent education as Not / Never Going to School and Not / Not / Completing Elementary School, namely 1,566 people, then Senior High School, which is 1,424 people. Meanwhile, based on their main employment status, the population who work as farmers is 46,705 people, civil servants have 4,041 people, work as independent businesses 14,613 people, work in the informal sector including agricultural laborers, 61,319 people.

Strategies to overcome unemployment and increase farmers' income, the local government of Bantaeng Regency has made various innovations and breakthroughs in regional development, especially the agricultural sector. There are eight sub-district regions that excel in the agricultural sector. For this reason, the local government has a mission "Bantaeng as a center for technology-based seed development. Innovations that are quite popular are corn seeds, 'lokana' brand onion seeds, potato seeds and rice seeds. This nursery technology innovation can increase farm income because it can be sold to farmers from areas in South Sulawesi. Apart from innovation in nurseries, local governments are also making innovations in the livestock and plantation sectors. Local government innovations in the agricultural sector have turned out to be many changes for Bantaeng Regency. This is in line with the concept of Osborne and Brown (2011) and William and Singh (2009), that the public sector innovations contribute to the improvement of compliance and quality of community. One of the strategies for sustainable agricultural development by local governments is the construction of reservoirs to control floods and function to meet the water needs of farmers and aquaculture. Currently Bantaeng is the center of economic growth, especially the agricultural sector in the southern part of South Sulawesi Province. The infrastructure development is complete enough that it is consciously starting to build its economy. Land that was not optimal has become optimal. The local government continues to encourage the capacity of farmers and related government officials and strive to meet the various needs of farmers. 


\section{Literature Review}

\section{Regional Government Management}

Understanding the various issues in local government management is very important in examining more deeply about the innovations practiced by a local government. Watson and Hasset (2003) suggest several important aspects in local government management (a) the relationship between officials and employees in a professional manner, (b) transparent and accountable financial and budget management, (c) public apparatus management (d) more regional government, productive and responsive, (e) citizen participation in local government. The local government understands and proactively studies and analyses the needs of its people, not that the people continuously convey their wishes to the government. In Watson and Hasset (2003), it is stated that the importance of involving citizens to participate in local government is based on the assumptions of the democratic governance paradigm, which states that individuals who are elected by citizens as political officials represent the interests of the government to solve problems currently facing society. Furthermore Stewart (1995), management in local government is part of the public domain theory which has the characteristics of certain objectives, conditions, tasks that must be understood in local government management.

The characteristics of the area indicate its name and identity, the area where it carries out functions in a focused manner, the area provides boundaries in order to achieve effectiveness and efficiency. Local authorities linked to the external environment, carry out open organizational tasks so that management is multi-contact. The main task of the local authority is to exercise the power of public government so that it must have accountability that is assessed by the public. Local authorities are given duties and obligations by law as providers of public services. Local governments are not only required to fulfil economic, effective, efficient principles but the principles of equity and equality must also be considered.

Local governments are faced with an increasing population, limited agricultural land, increasing people's basic needs and must be fulfilled, forcing public sector organizations to innovate as an integral part of government management strategies to be superior to other local government management in Indonesia. According to Porter (1998), that an organization to outperform, innovation should be an important part of excellence. Beaver and Prince (2002), 
nature, composition and quality of management are central to the innovation and performance of any organization, where performance is defined and measured in terms of its relationship to increased income and social welfare. The role of regional leaders is very decisive for economic growth and the improvement of community health. As Deschamps (2005) argues that transformational leadership is a factor that influences innovation in organizations. Tricahyadinata (2013) also points out that effective leadership includes skills and competencies, the ability to listen, the ability to motivate and the ability to learn are prerequisites for being creative and innovative in advancing the organization according to its vision, mission and goals.

United Nation through the Department of Economic and Social Affairs (UNDESA) in 2006 stated that generally innovation in government is a creative idea which, if implemented successfully, will help solve urgent public problems. Government innovation is the implementation of new ideas and new ways to achieve maximum results in doing work. Furthermore, Vigoda-Gadot, et al. (2006) on the relationship between innovation and public administration thinking, that the position of the concept of innovation in the development of public administration is on the new public management doctrine. Innovation studies are developed in line with efforts to maintain and even develop the ability to compete or compete in an organization.

\section{Innovation and Bureaucracy}

Hannu (2010), view that innovation does not only produce quality products, but also produces new products that keep up with the changes and tastes of the community that are constantly evolving. Furthermore Jasfar (2012), innovation as a process and result of the development and mobilization of knowledge, skills and experience to create or improve new products (goods and services), work processes and systems, which provide meaningful and significant value for socio-economic improvement. Public. In line with Mulgan \& Albury's view in Muluk (2008), successful innovation is the creation and implementation of new processes, service products and service methods which are the result of real development in terms of efficiency and effectiveness. Service product innovation comes from changes in the form and design of a product or service, while process innovation comes from a continuous quality renewal movement and refers to changes in the organization, procedures, 
and policies needed to innovate. Innovation in strategy or policy refers to a new vision, mission, goals and strategies and their reasons for departing from existing realities.

Henry (1988) suggests that the ability to make change, innovation, adaptation is very important in every form of organizational life. Organizational change is strongly influenced by technological, environmental, and human interaction factors with technology and the environment (Ahmad, 2018). According to Osborne \& Gaebler (1992), public sector managers are encouraged to find new ways of working and innovations in order to obtain maximum results in privatizing government functions. Hirotaka Takeuchi in Muluk ( 2008 ) states that innovation can be understood in the context of behavior change and is closely related to an organizational environment that is dynamic and developing. Furthermore, Rogers (2003) explains that innovation is a creative idea, practice, object that is considered new by certain individuals or work units and is adopted by others. Can be explained that an innovation can be either new products or new services, technologies and prose s new production, system and structure and the new administration, a new plan for the members of the organization. Innovation is needed in the public sector because the public sector has the task of running the country which is related to the interests and touches the lives of many people (Wijayanti, 2008).

The concept of bureaucracy is interpreted as a process and system that is created rationally to guarantee an orderly, definite and easily controlled work mechanism and system (Sa'id, 2010). Max Weber in Sa'id (2010) argues that bureaucracy is a routine administrative system that is carried out in uniform, organized in certain ways, based on written rules by people who are competent in their fields. Furthermore, Sa'id (2010) argued that the bureaucracy is a government institution that carries out state duties including government duties as a public servant, and implementing development for the welfare of society. Based on the various theories described above, the Bantaeng Regency Government as a public bureaucracy needs to continue to innovate in order to make it easier to achieve predetermined goals and solve agricultural problems in the regions.

\section{Methods}

In this study using a qualitative approach (Huberman, 2014). This type of research is descriptive to describe and analyze agricultural sector innovation as an effort to accelerate 
agricultural development and farmer welfare in Bantaeng Regency. Determination of informants in the study was carried out by purposive sampling in the field with the criteria that the informants were believed to have good and valid data. Key informants ( key informants) are the Head of the Agriculture Office and related leadership elements, the Head of the Food Security Agency, the sub-district heads, village heads, extension agents, farmer group heads, and community leaders. The data collection techniques in this study are: Observation, In- depth interview and Focus Group Discussion (FGD, documents that support the analysis and presentation of the objectives of this study.

\section{Results and Discussion}

The results showed that there are three main reasons the local government of Bantaeng Regency has made innovations in the agricultural sector, among others, the population has increased by 187,626 people and agricultural land is increasingly limited to an area of 27,074.45 hectares, and farmers' income has not been maximally impacted on the level of welfare of the unstable farming community, poverty rate is quite high. The innovation implemented by local governments is in line with Terziovski's (2007) view that innovation in the application of resources creates added value for society and organizations by developing and improving new products, work processes and high quality services. Furthermore, Wijayanti (2008) suggests one indicator of the success of local governments in developing their regions the ability to create innovations and breakthroughs in increasing the income and quality of life of the community.

Borins (2001), argues that the development of innovation in the public sector and global public management is driven by: (a) demands for people's rights through the election mandate, (b) the emergence of a regional leader who brings new ideas and concepts for regional improvement and progress, (c) there is a crisis that must be anticipated for the possibility that will occur in the future. Borins' view regarding the crisis has appeared in Uluere Subdistrict that $90 \%$ of the debt area has been converted into horticultural land, so that every time there is prolonged rain there is flood in Bantaeng City because water infiltration in the mountains is decreasing.

In the context of national development, especially in the agricultural sector, innovation in the public sector is essential because it requires acceleration or acceleration in advancing 
the economy and social welfare. However, the challenge faced by regional level government is the difficulty of some government officials and society in adapting to environmental changes. In terms of innovation, local government is very much needed to get the best solutions to various problems faced by the community, business actors, and the government. The results of research by Ahmad (2018) show that the toughest challenges in implementing innovations created by the government are field executing officers and people having difficulty leaving conventional old work patterns. In addition, some government officials and society as objects of innovation have difficulty adapting to modern technology (Ahmad et al, 2020).

According to Kholillullah (2013) the government in Indonesia continues to innovate in the agricultural sector in realizing national food security. Furthermore, Sangkala (2013) emphasized that local government has a creative idea that is implemented to resolve internal and external pressures. The right innovation will bring about changes in policies or programs that lead to recent improvements in the organization (Rogers, 2003). Bantaeng Regency under Nurdin Abdullah's ten-year leadership (2008-2018) and the current regent continue to carry out various agricultural development innovations as a superior strategy and program to open new jobs and increase farmers' income and welfare.

The goals and benefits of regional innovation include: (1) Increasing regional competitiveness, (2) Increasing the welfare of local communities, (3) Realizing better services for local communities, (4) Realizing good governance, (5) Strengthening local government institutions (6) Maintained loca wisdom . • Bantaeng Regency Government needs innovation to advance its region so that it can compete with other regions in Indonesia. Therefore, the innovations made by the Bantaeng Regency Government include :

1. Independent Village Acceleration Program

In the Bantaeng District Mid-Term Development Plan 2008 - 2013, the Desa Mandiri program is a village capable of producing specific commodities that have market share at the local, domestic and global levels. The underlying assumption of this strategy is that with the development of each country to manage the potential in their own way, then automatically the development goals such as growth of the economy, the level of income of the state and society, as well as improving the welfare of the community and others will be met in accordance with the conception kemandirian location which is the academic 
reference for the long-term development approach of South Sulawesi. This concept is a valuable lesson from Japan's Oita Prefecture, which in 1979, as stated by Teguh Prasojo and Eko Kurniawan from the Faculty of Social and Political Sciences, University of Indonesia, created the concept of "One Village, One Product" (OVOP), which proved able to change the previously economically backward Oita become an economically successful area.

Based on the results of the FGD which was attended by the Secretary of the Agriculture Service, agricultural extension agents and farmer groups, during the ten years the leadership of the regional head (Nurdin Abdullah) was able to change the management of less productive agricultural areas to be more productive according to the superior commodities that have been clustered. All villages in Bantaeng District have been independent, despite different levels of income and community welfare. Farmers horticulture located in the Villages in the District Uluere with leading commodity onions, potatoes, carrots, cabbage have an income sufficient height and welfare better. Likewise, lowland rice farmers who are supported by superior rice seeds with a harvest period twice a year are quite significant in supporting self-sufficiency and food security and have an impact on increasing farmers' income. Meanwhile, plantation farmers in Tompobulu Subdistrict plant superior coffee commodities, cultivating durian without aroma and seasonlessness and various other long-term tree crops which are significant in increasing farmers' income and welfare. Meanwhile, cattle, goat, horse, and poultry (broilers, laying hens, and village) business farmers support the fulfilment of the needs of the Bantaeng and surrounding communities and contribute to increasing farmers' income and welfare. In addition, an independent village can be realized by the existence of a significant allocation of village funds with the acceleration of rural development. Government policies related to the use of village funds for village road development, empowerment of village communities are able to encourage farmers to implement programs to accelerate agricultural development.

2. Technology-Based Seed Producing District

Since 2012 the government has provided a budget of Rp. 2 billion to buy seeds from farmers which will then be managed by the Agriculture Service and other related 
agencies. The Department of Agriculture has the function and task of breaking down the seeds, then printing the seeds through a tissue culture laboratory in collaboration with the Southeast Asian Regional Center for Tropical Biology. The seeds produced from the laboratory were not cut off. Not only used by farmers in Bantaeng, but almost all areas in South Sulawesi hope to use superior seeds from the decomposition in Bantaeng. The seeds that are popular with farmers are certified shallots, superior rice seeds, G1, G2, G3 potatoes, superior corn seeds, taro, and carrots.

3. Movement of the Legowo-21 Planting System,

To increase agricultural productivity in Bantaeng Regency, innovation is needed in its development and cropping patterns. The land for paddy fields in Bantaeng Regency in 2018 was only 7,523 ha (18.32\%) of the total area of Bantaeng Regency, namely 395, 83 km2 which required the Bantaeng Regency Government to seek efficient cropping patterns in terms of land use while maximizing agricultural production. Thus, the planting pattern of Legowo 21 is considered the most suitable with the contours and conditions of land availability in Bantaeng Regency. As a result, farmers can produce half more rice than usual. Based on the results of the interview with the head of the farmer group, it was stated that the advantages of the Legowo 21 planting system were the wider open space between groups of plant rows, making it easier for farmers to fertilize and water. Besides that, as long as this system is implemented, it can increase crop productivity which has an impact on increasing farmers' income and welfare. Even so, there are still members of farmer groups who are accustomed to the scatter crop system, so that the growth of rice plants is not optimal and productivity is lower.

4. Development of Agro-tourism Areas in Uluere,

Development of Agro-tourism (Apple and Strawberry Farms ) In view of the success of apple and strawberry farmers in Batu Malang, East Java Province and in Lembang Bandung, West Java Province, motivates the Bantaeng Regency Government to do the same. It is more convincing to Regency Government after knowing the climate and weather in Bantaeng the same as in the two regions of the apple and strawberry. So, the Bantaeng Regency Government then took the initiative to develop agro-tourism by developing the two types of fruit commodities on a community-based basis. The farmers are then expected to prepare the land and the seeds to be prepared by the Bantaeng 
Regency Government. As a result, the community's strawberry and apple gardens have provided economic value. With this new source of income for the community, it is hoped that their income and economic conditions will also increase which of course will affect the PDRB per capita of the people of Bantaeng Regency. Based on the results of field observations in September 2020, the condition of the Agro-tourism Area did not show any significant development, because farmers considered the existing plants to be less productive . Farmers prefer to plant vegetables in the area, especially shallots, potatoes, carrots and cabbage because of their higher economic value.

5. Developing Enterprise owned by Village (BUMDes)

Is an agency that manages the potential of the village for the welfare of villagers. The Bantaeng Regency Government has succeeded in encouraging the growth and development of BUMDes well. All villages have BUMDes, even in 2010 each BUMDes has received capital assistance of 4.6 billion, or each village received 100 million in assistance. This development has improved the economy of the Bantaeng community to the village level.

6. Developing Industry, Agricultural Product Processing

The policy for the development of the agricultural product processing industry includes the development of the product packaging and packaging industry to bring something new to the Bantaeng community. The development of a marine product canning industry was also carried out so that the development of a carrot product processing industry such as SNEWOTO chips. The products of the Bantaeng agricultural processing industry have even entered a number of markets outside Bantaeng Regency and can be found in mini markets.

\section{Development of Cow Insemination Techniques}

The innovation aims to improve the quality of cattle through artificial insemination technology and laser punching. The technology applied has been able to increase the number of cows since 2009 until now with superior quality. Many regions have come to study in Bantaeng for the development of cow insemination technology.

8. Utilizing Livestock Waste for Biogas in Rural Areas

Villages with a lot of livestock use waste as alternative energy. The utilization of this biogas indirectly helps reduce the community's need for gas, which is quite expensive and 
varies in remote villages. Besides being used as alternative energy, livestock waste is also used as solid and liquid organic fertilizer.

9. Utilizing Food Waste into Feed

In addition to using livestock waste to be useful for society and agriculture, food waste is transformed into something meaningful for animal feed. The breakthrough utilizes food waste from coffee, cocoa, kapok seeds and other plantations to become animal feed.

10. Bantaeng Taro Breeding

Kampung Bokara as a taro breeding center. Areas that are above the height of 300 meters above sea level are considered suitable as breeding grounds. Taro breeding is equipped with a tissue culture laboratory, so it can accelerate the need for export-based plant seeds. Taro is currently a major concern because of the increasing demand from overseas. 11. Cultivating Durian Without Aroma and Without Season,

At any time, durian fruit in Bantaeng can be enjoyed. Durian fruit that is developed has low cholesterol levels. This durian is the result of engineering developed with fertilization technology so that the results are better than the original. Although initially durian cultivation was still on a small scale, the impact was enormous. This durian plantation is located in Kacidu Village, Tompobulu District, with an area of 2 hectares. However, until now, durian cultivation is increasingly in demand by farming communities in neighbouring villages.

12. Cattle Livestock Business Insurance

The number of insured cows is 3000 heads or $(100 \%)$ according to the target. Insurance Provides protection to breeders who suffer losses due to their livestock having the risk of dying from illness, dying from childbirth, dying from poisoning or accidents, and being lost due to theft. In addition, the insurance company provides premium payment assistance to breeders of IDR 40,000 / livestock / year.

The benefits of cattle insurance for the community include: (a) the number of livestock is well identified, (b) availability of livestock cards, (c) monitored by animal health officers, (d) availability of online livestock data collection.

13. Rice Planting Business Insurance

There are 2,036 ha $(67.89 \%)$ of the target 3,000 ha which is covered by the insurance. The insurance provides protection to farmers when they experience crop failure due to 
drought, floods and attacks by plant pests. In addition, the insurance company provides premium payment assistance to farmers of IDR 36,000 / hectare / planting season. The farmers are satisfied to join the insurance because of the availability of water sources in the paddy fields that are registered with the insurance

14. Guaranteed availability of fertilizers and seeds.

The local government of Bantaeng Regency is trying to provide subsidized fertilizer for farmers, although it is supported by organic fertilizers. Besides guaranteeing the availability of fertilizers and seeds, the government strives to distribute powder fairly according to the needs of farmers every planting season. Although the budget allocated to the Agriculture Service Office is quite limited, the Agriculture Service Office tries to ensure that the fertilizer allocation for Bantaeng Regency can meet farmers' needs. In addition, the Department of Agriculture guarantees the availability of seeds and seeds to farmers and farmer groups every planting season.

Of the four dozen innovations in agriculture in Bantaeng, only the development of agro area that cannot be grown in accordance with its mission. This is because the community does not get direct and sustainable economic benefits

\section{Conclusion}

The innovation of the local government of Bantaeng Regency in agricultural development in the horticulture, plantation and livestock sector contributes to the creation of new fields, increased income and welfare of farmers, especially those sourced from unhulled rice (rice), seeds, shallots, potatoes, beans, coffee, cocoa, cengkeh, laying hens, broilers, chicken, goat, cow meat. However, farmers really expect assistance from extension agents in intensive planting and post-harvest periods to increase the quality and quantity of production. In addition, the household business group expects extension services and financing in the processing of agricultural products in order to produce quality products so that they can compete in the market. In addition, farmers expect government policies to guarantee price stability for agricultural products, especially horticulture. To encourage the growth of innovation in the public sector, especially the acceleration of agricultural development in Bantaeng Regency, several resources are needed such as farming capital, 
skilled human resources according to employment, technology utilization, and research and development of seeds and seeds, as well as post-harvest market orientation.

\section{Reference}

Ahmad, Badu (2018) Public Service: Theory and Practice, Bandung: Manggu Makmur Lestari. Ahmad, Badu, Yani, Ahmad Andi, Nasution, Adnan (2020) Impact of Public Service Innovation SMEs Busniess Climite in City Makassar, Indonesia. Journal of Critical Reviews, 7(16): 1977-1984.

Beaver, Grahan and Prince, Christopher (2002) Innovation, Entrepreneurship and Competitive Advantage in the Entrepreneurial Venture, Journal of Small Business and Enterprise Development, 9 (1): 28-37

Borins, Sandford (2008) Innovation in Government: Research, Recognition and Replication. Washington DC: Brookings Institution Press.

Deschamps, Jean-Phippe (2005) Different Leadership Skills for Different Innovation Strategies, Strategy \& Leadership, 33(5): 31-38.

Hannu, Littunen and Miika Varis (2010) Type of Innovation, Sources of Information and Performance in Entrepreneurial SMEs, European Journal of Innovation Management, 13 (2): 128-154.

Henry, Nicholas (1988) State Administration and Public Matters, Raja Grafindo Persada, Jakarta. Huberman, Miles, and Saldana, 2014. Qualitative Data Analysis (Translation). Jakarta: UI Press Jasfar, Farida (2012), Theory and Application of Nine Keys to Success of Service Businesses ; Human Resources, Innovation, and Customer Satisfaction, Jakarta: Salemba Empat.

Kholillullah, Ibrahim, M. (2013) The Capability of Agricultural Innovation in Jombang Regency in the Integrated Agriculture Program to Achieve Food Security, Journal of Public Policy and Management, 1(1): 137-148

Muluk, Khairul. MR (2008) Knowleadge Management; Keys to Success in Local Government Innovation, Malang: Bayumedia Publishing.

Osborne, David \& Ted Gaebler (1992), Reinventing Government: How and Entrepreneurial Spirit is Transforming the Public Sector, Reading MA, Addision-Wesley, Paper Prepared for the PMRA Conference, Oct 1-2, Columbia, Ohio. 
Osborne, S. and Brown, L. (2011). Innovation, Public Policy and Public Service, Delivery In the UK: The Word that Would be King. International Journal of Public Administration. 89(4):1135-1350

Porter, Michael and Stem, Scott (2001) National innovative Capacity; In The Global Competitiveness Report 2001-2002, New York: Oxford University Press.

Rogers, Everett M. (2003) Diffusion of Innovation. New York: Free Press.

Sa'id, M. Mas'ud, (2010) Bureaucracy in Bureaucratic Countries: Meaning, Problems and Deconstruction of Indonesian Bureaucracy, Malang, UMM Press.

Sangkala, (2013) Innovative Governance: Concepts and Applications, Yogyakarta: Capiya Publishing

Stewart, John (1995) Undestanding the Management of Local Government: Its Special Purpose, Conditions and Task. Longman Group UK Ltd.

Terziovski, Mile, 2007. Building Innovation Capability in Organizations: An International CrossCase Perspective. London: Imperial College Press.

Tricahyadinata, Irsan, 2013. Innovation Capability of Small and Medium Enterprises in Indonesia, Journal of Accountability, 10(1): 1-18.

UNDESA (2006) Innovation in Governance and Public Administration, Replicating What Works. New York: United Nations Publication.

Vigoda-Gadot, Eran, Aviv,Shoham, Nitza, Schwabsky, Nitza, Ruvio, Ayalla (2006) Public Sector Innovation for the Managerial and Post Managerial Era: Promises and Realities in a Globalizing Public Administration. International Public Management Journal, 8 (1):5781.

Watson and Hasset (2003) Local Governmant Management: Current Issues and Best Practices. New York: ME Sharpe

Wijayanti, Sri Wahyu, 2008. Innovations in Public Services . Journal of Public Administration, 4(4): 39-52

William D. Eggers and Shalabh Kumar Singh, 2009. The Public Innovations Playbook; Nurturing Bold Ideas In Government, Harvard Kennedy School. 